Review Article

\title{
Microbial-Induced Carbonate Precipitation: A Review on Influencing Factors and Applications
}

\author{
Junhui Zhang $\mathbb{D}^{1,2}$ Xiuzhi Shi $\mathbb{D}^{1,2}$ Xin Chen $\mathbb{D D}^{1},{ }^{1}$ Xiaofeng Huo $\mathbb{D}^{1},{ }^{1}$ and Zhi Yu $\mathbb{D}^{1}$ \\ ${ }^{1}$ School of Resources and Safety Engineering, Central South University (CSU), Changsha, Hunan 410083, China \\ ${ }^{2}$ School of Geology and Mining Engineering, Xinjiang University, Urumqi 830046, China \\ Correspondence should be addressed to Xiuzhi Shi; baopo@csu.edu.cn
}

Received 18 March 2021; Accepted 7 November 2021; Published 6 December 2021

Academic Editor: Paul Awoyera

Copyright (c) 2021 Junhui Zhang et al. This is an open access article distributed under the Creative Commons Attribution License, which permits unrestricted use, distribution, and reproduction in any medium, provided the original work is properly cited.

\begin{abstract}
Based on recent literary sources, this survey discusses the effects of main factors influencing the microbial-induced calcium carbonate precipitation (MICP), including the bacterial species, bacterial concentration, temperature, and $\mathrm{pH}$ value. While the MICP technology has been widely adopted to improve rock and soil characteristics, it has excellent development prospects in many other fields. The breakthrough solutions in the MICP technology are improving geotechnical and foundation sand properties, repairing cement-based materials, using mineralized film mulching to protect cultural relics, enhancing properties of tailings, desert control, and heavy metal environmental restoration, etc., are discussed. The experimental findings prove that MICP can improve the strength, stiffness, liquefaction resistance, erosion resistance, and permeability of geotechnical materials and maintain the good permeability and permeability of the soil and improve the growth environment of plants. It is an environmentfriendly bioengineering technology. Because microbial mineralization involves a series of biochemical and ionic chemical reactions, there are many reaction steps in the solidification process and the solidification effect of MICP is restricted and affected by many factors. The comprehensive analysis and optimization strategy on MICP industrial implementation should account for micro- and macro-scale effects: the type of bacteria, the concentration of bacteria and cementation solutions, ambient temperature, $\mathrm{pH}$ value, and other factors directly affect the crystallization type, morphology, and size of calcium carbonate from the microscopic standpoint, while the macro-scale factors control the rock and soil mineralization. The limitations and prospects of the MICP technology are outlined.
\end{abstract}

\section{Introduction}

With the continuous development of the global economy, large-scale construction projects encounter geotechnical engineering problems such as weak subgrade, karst foundation collapse, soil slope landslide, embankment leakage erosion, and soil freeze-thaw cracking in alpine regions. Given these engineering diseases, traditional physical methods such as dynamic foundation compaction, soil cushion replacement, cement mixing pile setting, and other measures have a heavy workload, long construction period, and high cost. They need to support the development of large mechanical equipment, which cannot be used in some special cases. The chemical method is to pour the chemical slurry into the target rock and soil. Because most grouting materials have strong alkalinity and biological toxicity, vegetation growth on the solidified rock and polluted soil becomes problematic, the environmental pollution is too large, and the application is limited in many cases.

Soil modification technology based on microbial-induced calcium carbonate precipitation (MICP) has attracted extensive attention in geotechnical engineering. The technology uses mineralizing bacteria in nature to induce mineral components (such as calcium carbonate, etc.) with a bonding effect to fill and repair cracks in stone materials and concrete materials, prevent building leakage, reduce the incidence of sandy soil liquefaction, and prevent soil erosion of sand/soil slope, sand dike erosion, piping, and other diseases $[1,2]$. 
Compared with the traditional physical/chemical soil modification technology, MICP has more advantages in the transformation of rock and soil properties: its construction method is simple, it almost does not produce toxic and harmful substances, it has less chemical pollution to the surrounding soil water environment [3], the concentration of bacteria liquid and bonding liquid used for the modified object is low, compared with the traditional chemical slurry, it is easier to infiltrate in the rock and soil materials [4], and it can be used for large-scale treatment of rock and soil [5]. In addition, the durability of mechanical or hydraulic properties of rock and soil improved by MICP can be guaranteed while ensuring its strength [6]. Therefore, the soil modification technology based on MICP has good application scenarios and promotion prospects.

At present, the known microbial mineralizing bacteria mainly include urease-producing bacteria, sulfate-reducing bacteria, denitrifying bacteria, oxidizing bacteria, etc. Among them, urease-producing bacteria have been widely studied and applied due to their low cost, relatively easy extraction and cultivation, good mineralization and cementation effect, and easy control of the reaction process. The process of bacterial mineralization can be simplified as follows: in bacterial metabolism, the negative charge on the cell surface adsorbs $\mathrm{Ca}^{2+}$ from the environmental solution. After urea is added to the bacteria, the urease secreted by the cells decomposes urea to form $\mathrm{CO}_{3}{ }^{2-}$ and $\mathrm{NH}_{4}{ }^{+}$plasma, and $\mathrm{Ca}^{2}+$ combines with $\mathrm{CO}_{3}{ }^{2-}$ to form calcium carbonate crystals on the cell surface (Figure 1). After a while, the whole cell was surrounded by calcium carbonate. After the bacteria became capsules, their living environment was limited, resulting in cell death. A large number of capsules formed a cemented structure, which played the role of bonding the microparticles in the geotechnical materials and filling the internal pores and cracks (Figure 2) [6, 8], and ultimately the performance of the geotechnical materials was improved. The main reaction equation is as follows [7]:

$$
\begin{aligned}
& \mathrm{Ca}^{2+}+\text { Cell } \longrightarrow \text { Cell }-\mathrm{Ca}^{2+}, \\
& \mathrm{NH}_{2}-\mathrm{Co}-\mathrm{NH}_{2}+2 \mathrm{H}_{2} \mathrm{O} \stackrel{\text { urea }}{\longrightarrow} 2 \mathrm{NH}_{4}^{+}+\mathrm{CO}_{3}^{2-}, \\
& \mathrm{CO}_{3}^{2+}+\mathrm{Cell}-\mathrm{Ca}^{2+} \longrightarrow \text { Cell }-\mathrm{CaCo}_{3} \downarrow .
\end{aligned}
$$

Among so many enzyme-decomposing bacteria types, Bacillus and Sporosarcina are the most selected bacteria in studies. These two kinds of bacteria have many advantages: strong adaptability to the environment, difficult aggregation between cells, the high specific surface area of cells, and they can use urea as energy and nitrogen source in metabolism. It can be transformed into $\mathrm{CO}_{3}{ }^{2-}$ and rapidly deposit calcium carbonate under the condition of adding $\mathrm{Ca}^{2+}$ salt solution. Due to the fast and high yield of calcium carbonate produced by Bacillus, the advantages of bacterial mineralization and cementation process, these two kinds of bacteria are mainly used in MICP experiments and application projects [7, 8].

Because microbial mineralization involves a series of biochemical and ionic chemical reactions, the reaction steps in the curing process are complex. The curing effect of MICP is restricted and affected by many factors. Scholars worldwide have experimentally derived qualitative and quantitative relationships between the crystallization process and effective calcium carbonate production. The roles of concentration and activity of bacterial solution, the concentration of cementation solution, $\mathrm{pH}$ value, soil particle size, and soil density in bacterial metabolism have been identified. These research results enabled the MICP reinforcement technology to safely, stably, and efficiently complete the reinforcement and transformation requirements of the target rock, soil, and geotechnical materials. This paper summarizes the most recent global research results on MICP concerning the key physical, chemical, biological, and abiotic factors influencing the microbial improvement of geotechnical materials. To provide some reference for the future theoretical research and engineering application of microbially reinforced geotechnical engineering materials, the account of these factors in the MICP optimization is discussed in detail.

\section{Microbial-Induced Carbonate Precipitation (MICP)}

Microbial-induced carbonate precipitation (MICP) technology has attracted global attention in the past two decades. Urease activity exists widely in bacteria, which is the most commonly used method to produce calcite by MICP. It is also one of the most important factors in research and application in the development of microbial cementitious materials. The importance of MICP and environmental protection has also been emphasized by Fujita et al. [9]. They studied microbial cement cementation of loose sand from three aspects: compressive strength, pore structure, and microstructure. In addition, the research on the repair of surface defects and cracks of cement-based materials by microbial cement featured two parameters of surface water absorption and compressive strength recovery coefficient. The research progress of microbial cement in repairing cemented loose particles, surface defects, and cracks of cement-based materials in China has been reviewed by Rong and Qian [10].

Calcium carbonate $\left(\mathrm{CaCO}_{3}\right)$ precipitation generally occurs through two different mechanisms: biological control and biological induction. In the process of biologically controlled mineralization, the nucleation and growth of mineral particles are mainly affected by organisms. Organisms synthesize minerals in their unique form, which has nothing to do with environmental conditions. Bio-induced mineralization refers to the production of calcium carbonate by bacteria. The type of minerals produced by this kind of mineralization process is mainly affected by environmental conditions. There is no special structure or specific molecular mechanism involved. Different types of bacteria and abiotic factors (salinity and medium composition) promote calcium carbonate precipitation in different environments in various interrelated ways $[8,11]$. The schematic diagram in Figure 3 illustrates the relevant principles of the MICP technology.

Calcium carbonate can precipitate rapidly in all the bacterial culture experiments providing urea and calcium, 

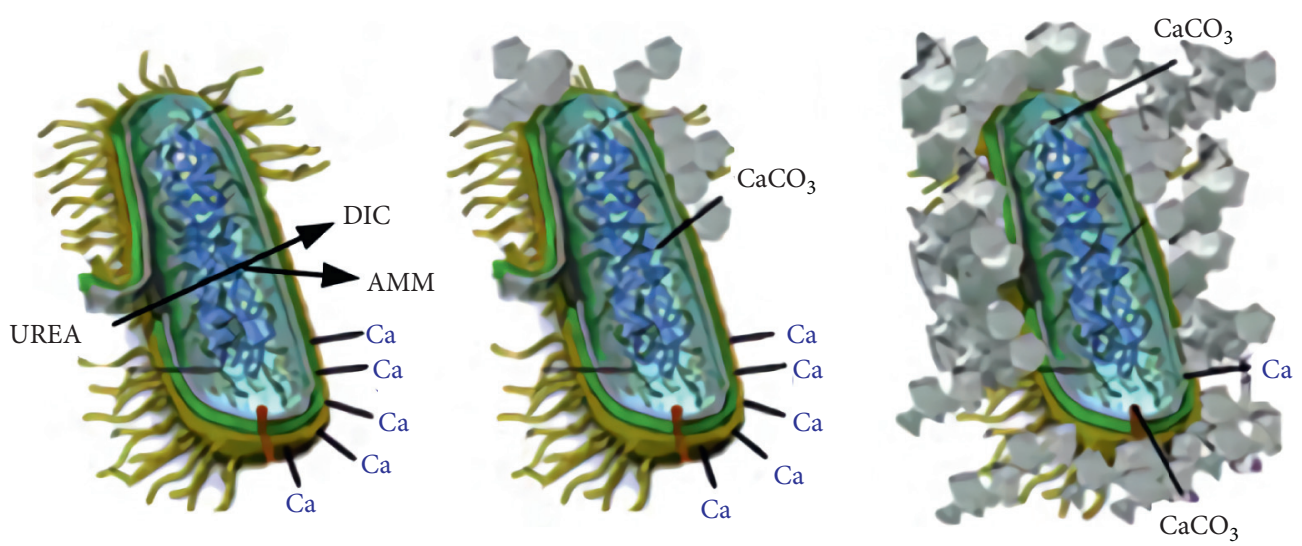

FIGURE 1: Schematic diagram of biomineralization of urease-producing bacteria [7].
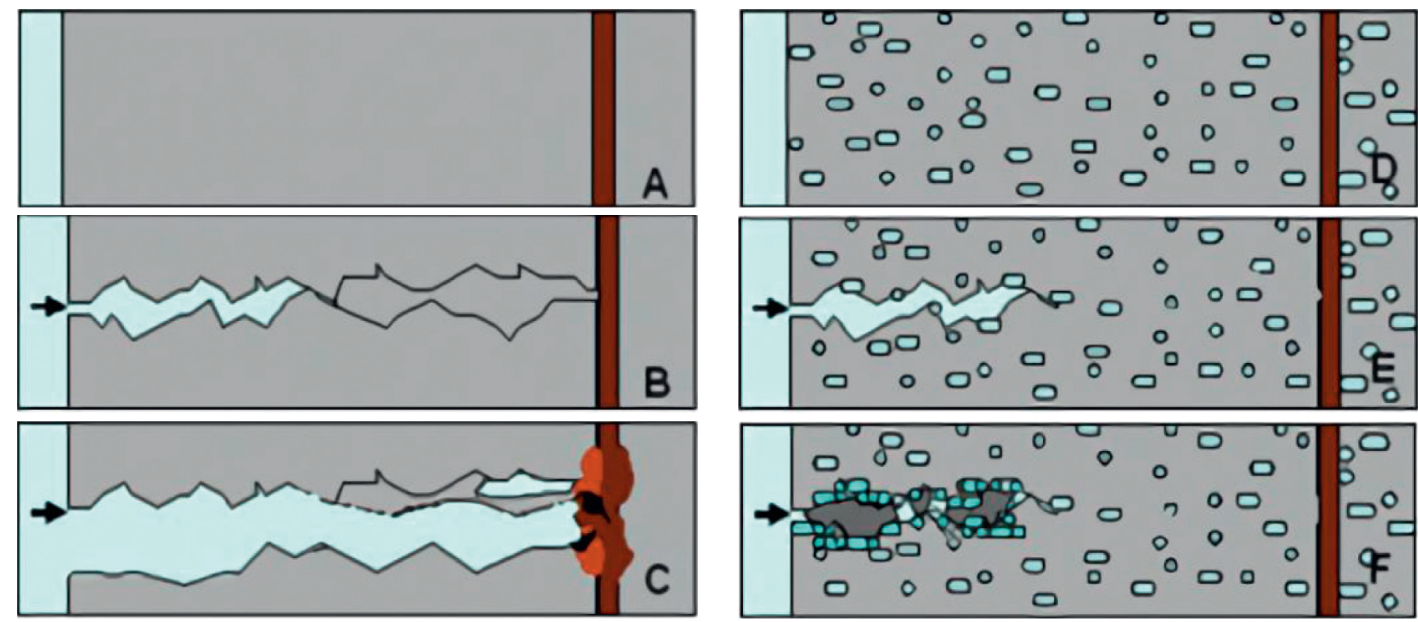

(a)

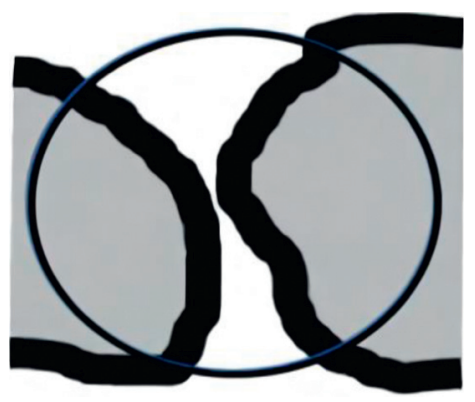

Equal thickness distribution

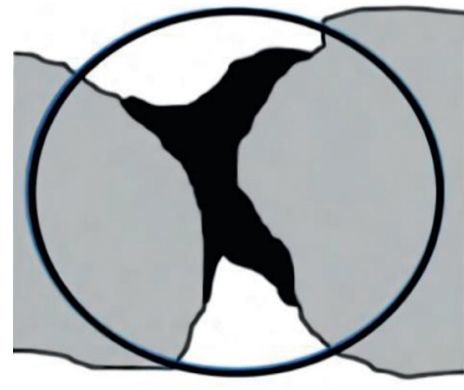

Optimal distribution

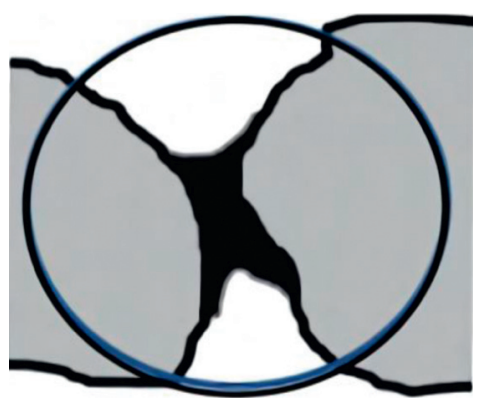

Actual distribution

(b)

FIGURE 2: Schematic diagram of biomineralization principle of urease-producing bacteria. (a) Schematic diagram of fracture repair principle. (b) Schematic diagram of MICP solidification and cementation $[6,8]$.

and the polycrystalline carbonate calcite is always the main product of X-ray diffraction analysis. The relationship between calcium concentration and equilibrium prediction obtained by Fujita et al. [9] indicated that the precipitation rate of calcium carbonate was directly related to the hydrolysis rate of urea.

The effect of calcium sources on the MICP process is quite significant. Therefore, the effects of four different calcium salts, calcium chloride (a), calcium acetate (b), calcium lactate (c), and calcium gluconate (d), on the formation of calcium carbonate crystals by Pasteurella kctc3558 have been studied by Gorospe et al. [12]. While preliminary test results revealed that the addition of any calcium salt would harm the urease activity of Pasteurella, the difference in calcium carbonate precipitation morphology patterns was found to be related to the calcium salt used. Different 


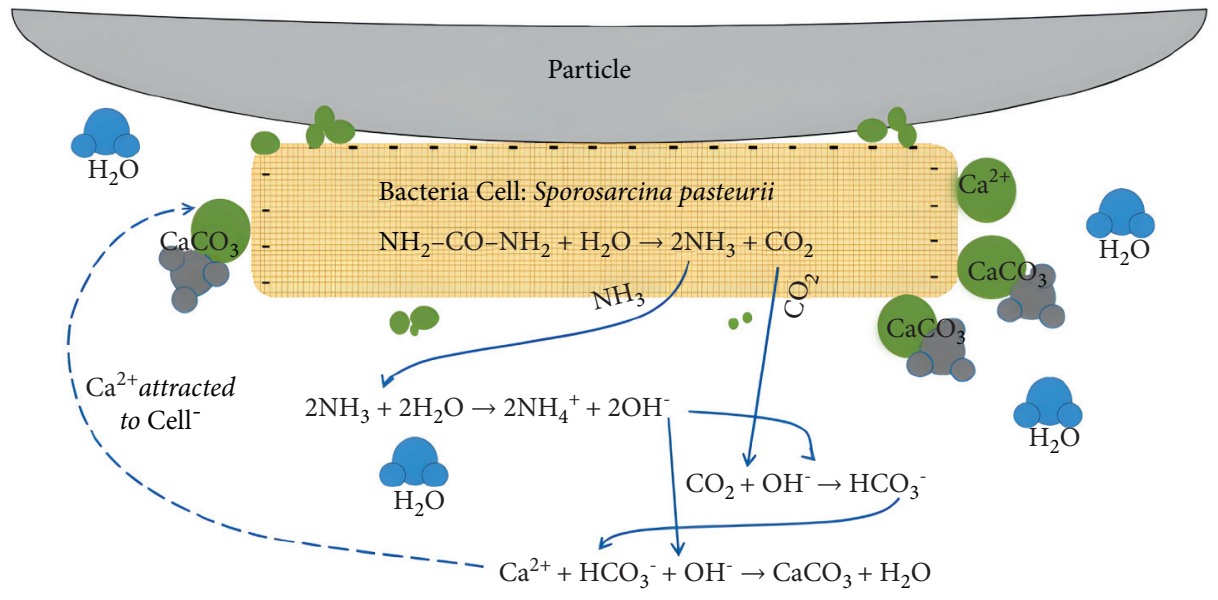

FIGURE 3: Schematic diagram of microbiologically induced calcium carbonate precipitation on the surface of particles.

calcium sources (calcium chloride, calcium oxide, calcium acetate, and calcium nitrate) were added, and Bacillus CR2 was used for MICP. The experiment lasted for seven days, and the bacterial growth, urease activity, calcite yield, and $\mathrm{pH}$ value were measured. The results showed that calcium chloride has high urease activity and high calcite yield, being a good calcium source for the MICP process [13].

The effect of the environment on MICP was evaluated by soil column tests and intermittent tests [14]. Microbial growth and mineral precipitation were evaluated in fresh water and seawater. Environmental conditions that may affect bacterial urealytic activity, such as ammonium concentration and oxygen utilization, as well as the urealytic activity of living and lysed cells, were evaluated.

The treatment formula, injection rate, and soil particle characteristics are other factors to evaluate the influence of uniform cementation induction in the soil. The effect of ground conditions on MICP was analyzed in the study [15]. The effect of microbial cementation in treated sand and silt, silica sand with different relative densities, silt with different relative compaction, and weathered soil with different particle size distributions was tested. The microbial cementation degrees of sand, silt, and weathered soil samples were quantitatively analyzed by scanning electron microscope (SEM), X-ray diffraction (XRD), energy dispersive X-ray (EDX) spectroscopy, and mapping analysis. According to the test results, a considerable amount of microbial cementation is estimated according to the soil conditions. Therefore, implementing this new biological grouting on the soft foundation can improve the strength and stiffness of the soft foundation.

In the process of MICP reaction, Kitamura et al. [16] studied the controlling factors and mechanism of calcium carbonate polymorph crystallization by adding sodium carbonate solution to calcium hydroxide suspension. A series of research results showed that if the concentration of calcium ion was equal to or close to the solubility of calcium hydroxide, the low concentration of carbonate ion in the "diffusion field" around sodium carbonate solution droplets (low local supersaturation) was conducive to the crystallization of aragonite.

\section{Key Influencing Factors of MICP}

The conventional precipitation process of calcium carbonate is simple, being mainly affected by calcium ion concentration, $\mathrm{pH}$ value, and effective nucleation site [8]. However, MICP is a very complex biological and chemical process. MICP is mainly affected by the following key factors: (i) bacterial species, (ii) bacterial concentration, (iii) ambient temperature, (iv) $\mathrm{pH}$ value, (v) the ratio of cementation solution (calcium ion concentration), (vi) the nature of cemented materials: soil, sand, or others), and other factors. The precipitation of $\mathrm{CaCO}_{3}$ needs enough calcium and carbonate ions to produce the required amount of precipitation for cementation.

3.1. Bacterial Species. The type of bacteria influences the crystal form, morphology, and deposition rate of calcium carbonate. The cementation effect of microorganisms on geotechnical materials is determined by different crystal types and the amount of calcium carbonate generated by MICP [17].

Therefore, it is of practical significance to study the mineralization characteristics of different types of bacteria for bacterial reinforcement and engineering applications. Different bacteria have different characteristics of calcium carbonate crystals. Mastering the mineralization characteristics of different bacteria can maximize the cementation effect of rock and soil in engineering applications. Scholars worldwide investigated the mineralization characteristics of different types of bacteria in recent years. Many valuable studies on the types and control of calcium carbonate crystals formed by mineralization, adaptability of different bacteria to the environment, and MICP expansion from laboratory conditions to the field have been performed to improve the urease production of bacteria. SEM images of carbonate crystals precipitated by different bacterial species in the research process have been obtained and analyzed by Dhami [18], as shown in Figure 4.

According to the production of urease, carbonic anhydrase, extracellular polymer, and biofilm, Bacillus megaterium, Bacillus cereus, Bacillus thuringiensis, Bacillus 


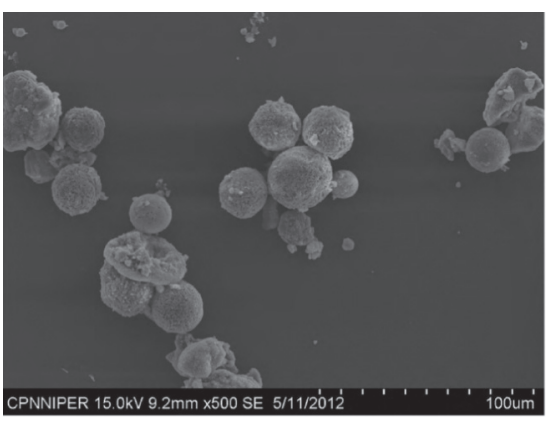

(a)

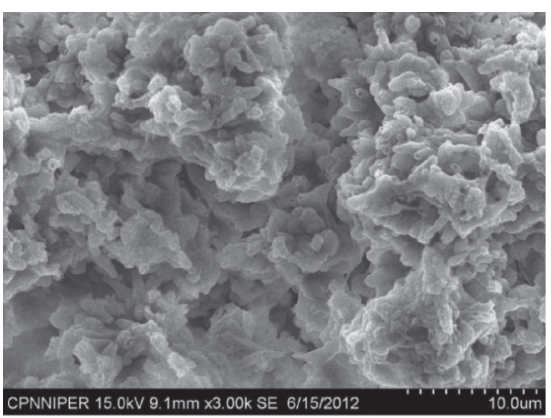

(d)

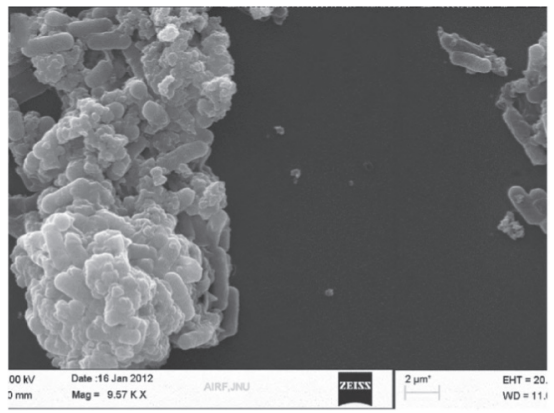

(g)

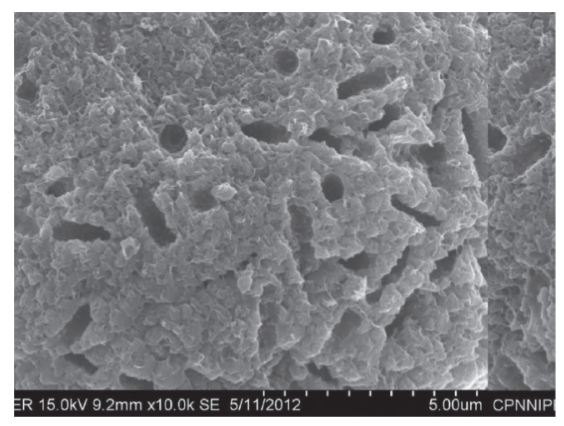

(b)

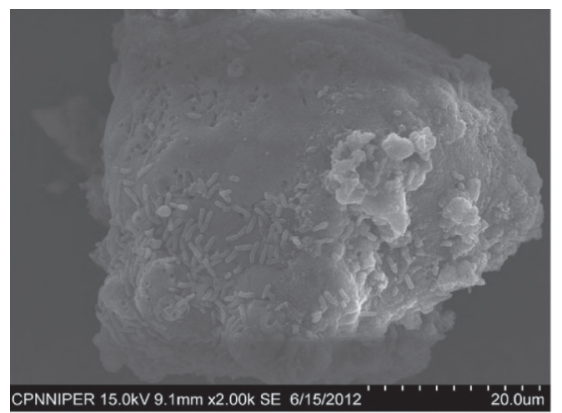

(e)

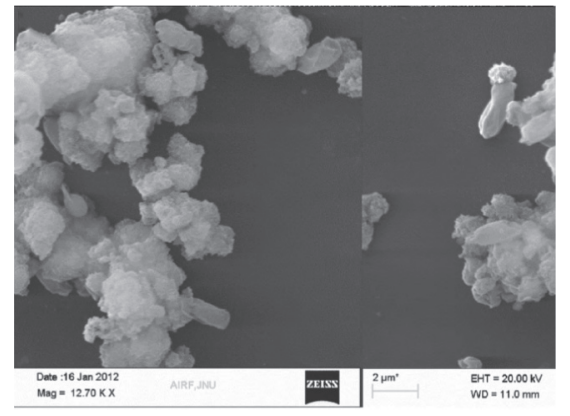

(h)

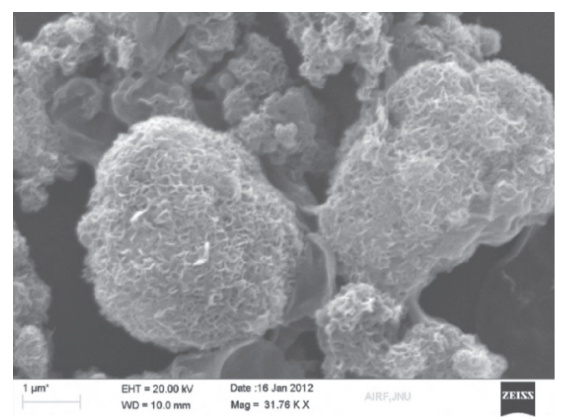

(j)

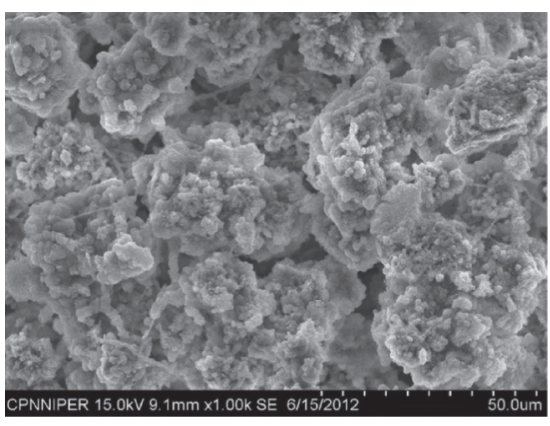

(c)

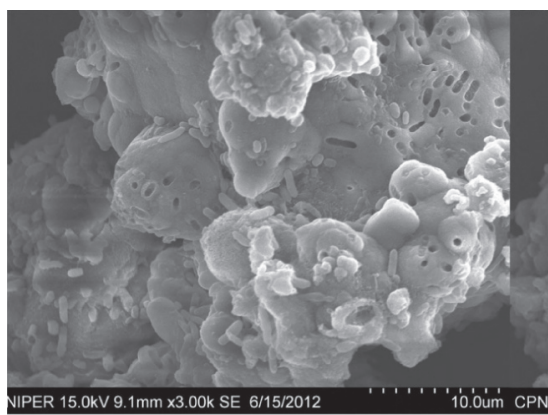

(f)

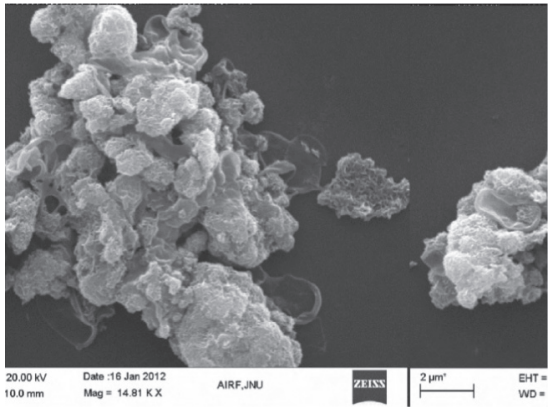

(i) B. thuringiensis (Bt), (g, h) B. subtilis (Bs), and (i, j) L. fusiformis (Lf).

subtilis, and Clostridium were isolated from calcareous soil. All bacterial cultures were incubated in niobium medium with urea (a $2 \%$ concentration) and $25 \mathrm{mM}$ calcium chloride $(\mathrm{pH}=8.0)$ at $37^{\circ} \mathrm{C}$ for three weeks. Among the isolates, Bacillus megaterium showed the highest urease activity $(690 \mathrm{U} / \mathrm{ml})$, followed by Bacillus thuringiensis $(620 \mathrm{U} / \mathrm{ml})$, Bacillus cereus, Clostridium, and Bacillus subtilis, which produced 587, 525, and $515 \mathrm{U} / \mathrm{ml}$ on day 5, respectively [18]. Bacillus megaterium plays an important role in repairing building materials, soil reinforcement, heavy metal recovery, and surface protection of cement and concrete materials. At the same time, it can also degrade the insoluble phosphorus compounds in the soil, making them soluble substances that crops can absorb. When Bacillus megaterium and Bacillus 
sphaericus were cocultured, they exhibited the effects of nitrogen fixation and synergism, which were very suitable for making microbial fertilizers.

The culture experiment of Okwadha and Jin [19] on Sporosarcina pasteurii strain ATCC 11859 showed that the decomposition rate of urea positively correlated with the bacterial cell concentration. Within their respective economic advantages, urea concentration, calcium concentration, and bacterial cell number were directly proportional to the amount of $\mathrm{CaCO}_{3}$ deposition. According to the experimental analysis, the main components of calcium carbonate were calcite crystals and a small number of aragonite crystals. The above study confirmed the quantitative effect of bacterial plugging on the hydraulic conductivity of porous media. The amount of $\mathrm{CaCO}_{3}$ precipitation was directly proportional to the amount of bacterial cell deposition. The number of depositing cells determined the relative reduction rate of hydraulic conductivity.

The number of depositing cells was affected by the density of bacterial cells introduced into the bacterial suspension [20]. The phenotypic mutant of Bacillus pasteurii (MTCC 1761) was developed by ultraviolet irradiation. The calcite produced by this mutant through biomineralization was very active. The screening and cultivation of mutant strains could provide a more effective strategy for plugging the gaps in building structures [21]. The relevant experiments have been carried out to find microorganisms with satisfactory performance in various environmental conditions (not limited to laboratory temperature). Among all the tested urealytics, Bacillus sphaericus was the most suitable for biodegradation in practice [22]. Urease activity is an essential factor in the process of MICP. Using immobilized enzymes instead of whole immobilized cells provided a better repair effect, according to Bachmeier et al. [23].

The screening and cultivation of mutant strains may provide a more effective strategy for plugging the gaps in building structures. This is also a typical case of cross-application of biotechnology, which has a good development prospect. It is also the key direction of cross research between geotechnical engineering and biological science.

\subsection{Bacterial Solution Concentration and Cementation So-} lution Concentration. Bacteria are important for the formation of calcium carbonate crystals in the process of MICP. Tourney and Ngwenya [24] reported that bacterial extracellular polymeric substance (EPS) positively affected the crystal type and morphology of $\mathrm{CaCO}_{3}$ precipitation, which was vital for the cementation of geotechnical materials. EPS could inhibit the precipitation of aragonite and promote the precipitation of calcite, which was beneficial to the MICP process.

The number of microorganisms in a mineralized environment strongly impacted the concentration and supersaturation degree of $\mathrm{Ca}^{2+}, \mathrm{CO}_{3}{ }^{2-}$ plasma $[25,26]$. In the experiment of culturing Bacillus Pasteurella ATCC strain 11859 at $25^{\circ} \mathrm{C}$ performed by Okwadha and Jin [19], the ionic strength was proportional to the concentration of urea, calcium, and bacterial cells. Bacterial cell concentration on urea decomposition rate exceeded the initial urea concentration.

The concentration of the bacterial solution was found to strongly influence the morphology of calcium carbonate crystals [27]. Most calcium carbonate crystals were spherical or nearly spherical at a $100 \%$ concentration of the bacterial solution. When the bacterial solution concentration was reduced to $50 \%$, some crystals had irregular shapes, while others appeared as regular cuboids or aggregates. When the concentration of the bacterial solution was further reduced to $25 \%$, the share of regular cuboids or aggregates in the crystals further increased; in a pure aqueous solution, the crystals were orthorhombic hexahedral single crystals, twins, and their aggregates. The crystal morphology at different bacterial concentrations is shown in Figure 5.

The comparative tests of two bacteria concentrations, two culture media, and six cement solution concentrations showed that the composition of culture medium had no direct effect on MICP efficiency, while the type and concentration of cement solution affect the strength of mortar [25].

In the design and implementation of MICP, the concentration of cementation fluid was found to play an important role $[28,29]$. Compared with high-concentration cementation fluid, low-concentration one produced more uniform and stronger crystals. However, the latter operation process needed more steps, time, and costs than the former one. Given the engineering nature of soil improvement, more simple and effective methods need to be further explored.

Al-Thawadi and Cord-Ruwisch [30] revealed a positive correlation between the average particle size and the cell concentration, while the urease activity increased with the cell concentration. The precipitated crystal grew with the carbonate production rate, so the bacterial concentration was reported to be the key parameter controlling the crystal size. In practical application, it may be more advantageous to increase the concentration of bacteria in coarse sand. The average size of the sphere increased with the concentration of the cementation solution (urea and calcium ions). At a concentration of the cementation fluid of $10-250 \mathrm{mM}$, the spherical size increased sharply; when the concentration exceeded $10-250 \mathrm{mM}$, the spherical size growth became saturated. Therefore, the optimal concentration of bacteria liquid and cementation liquid was considered beneficial for improving the cementation strength and maintaining good air permeability.

3.3. Ambient Temperature. The change of environmental temperature will directly affect bacteria's growth and metabolic activities, thus changing the deposition rate and yield of calcium carbonate, changing the type and morphology of crystals. The change of temperature will affect the crystal size and the cementation mode of purpose calcium carbonate between soil particles, which will directly affect the effect of microbial mineralization and cementation. Therefore, it is necessary to study the effect of temperature on MICP activity $[19,31]$. Studies have shown that the catalytic activity of 

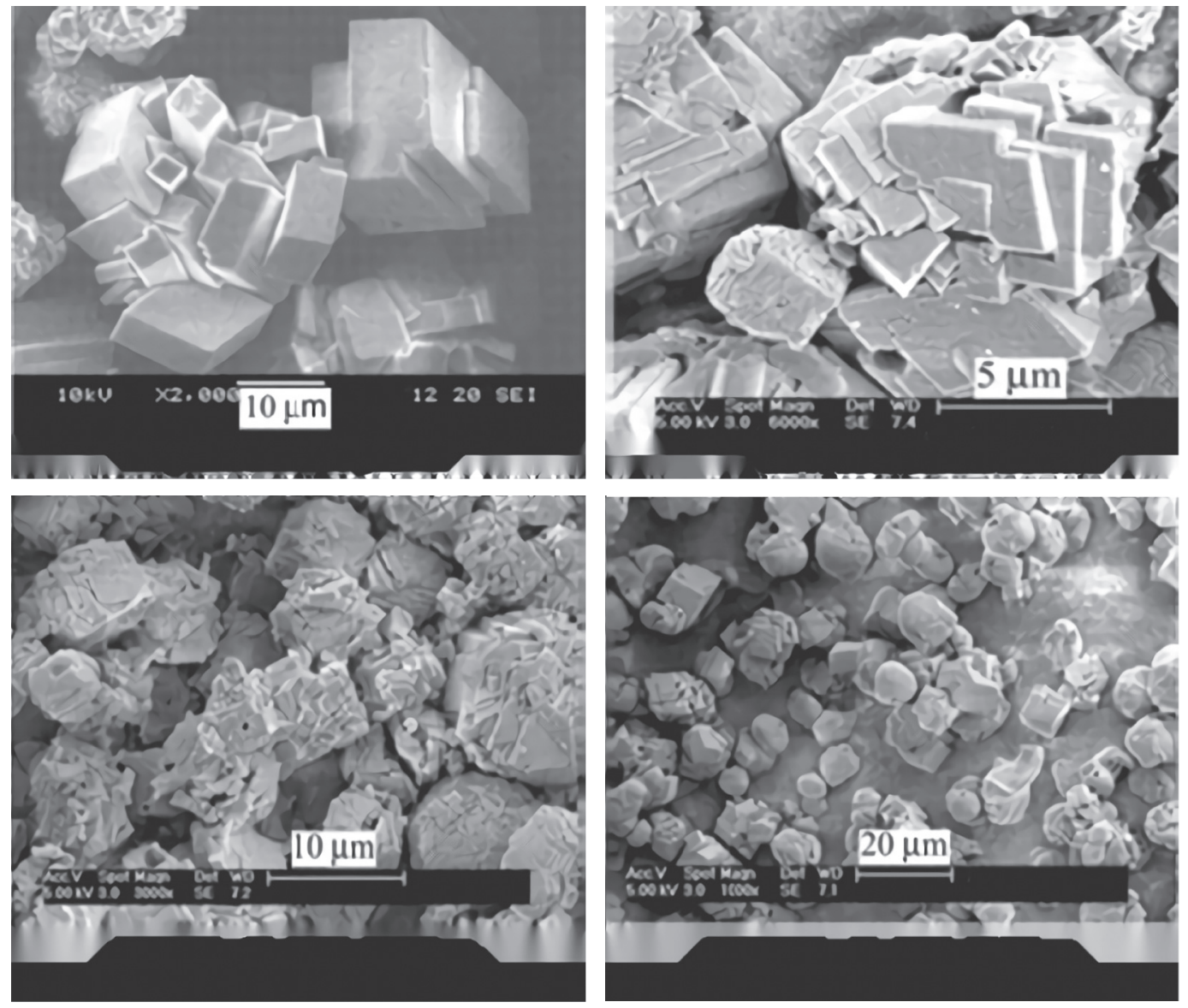

Figure 5: SEM of crystalline $\mathrm{CaCO}_{3}$ at different bacterial concentrations $\left(20^{\circ} \mathrm{C}\right)$ [27].

urease was the strongest at $20 \sim 37^{\circ} \mathrm{C}$ [19]. In this temperature range, intrinsic to most MICP studies, the urease activity increased with temperature. However, the successful practical application should envisage the bacteria activity adaptation within a wider temperature range.

In the MICP investigations $[2,32]$, the temperature effect on the biodegradation performance of different urealytics, including the reinforcement and protection effect of the treatment, the growth, and urealytics activity of urealytics at different temperatures $\left(10,20,28\right.$, and $\left.37^{\circ} \mathrm{C}\right)$, was analyzed. The results showed that Bacillus sphaericus was the most suitable for biodegradation under various environmental conditions among all the tested microorganisms. The effect of temperature on the morphology and quantity of biocrystals produced on limestone with different urealytic microorganisms was investigated by scanning electron microscopy, as shown in Figure 6 [22].

3.4. $p H$ Value. The $\mathrm{pH}$ value plays an important role in the metabolic activity of urease-producing bacteria, calcium carbonate deposition, and improvement of geotechnical properties. Most urease bacteria commonly used in microbial mineralization are suitable for growth in an alkaline environment. For example, the suitable $\mathrm{pH}$ value of Bacillus is about 9.0. An economic growth method for the large-scale culture of Pasteurella has been developed [33]. The organism was moderately alkalophilic, with the optimum $\mathrm{pH}$ for growth of 9.25. Under nonsterile conditions, sufficient biocoagulation activity could be cultivated through minimal upstream and downstream processing. The production cost was reduced by $95 \%$. In the new medium, a high level of urease activity (hydrolysis of $21 \mathrm{mmol}$ urea for 1 minute) was produced at a low cost ( 0.20 USD per liter), which was vital for the field application of MICP.

Since many engineering applications need to be implemented in an acidic environment, it is of practical significance to study the bacterial activity in different $\mathrm{pH}$ ranges. Recently, a scientific research team [34] used the MICP technology to study the mechanical properties of iron tailings under low $\mathrm{pH}$ conditions. Compared with the conventional solution, the calcium carbonate content of the Sporosarcina pasteurii (DSM 33) strain increased first and then dropped when the fluid $\mathrm{pH}$ changed from 4.5 to 6.5 under the condition of $1 \times 10^{8}$ cells $/ \mathrm{ml}$ bacterial solution, calcium carbonate content reached the maximum at pH 6. Compared with traditional cementation, the spray method using low $\mathrm{pH}$ bacteria solution could make the adhesive more uniform, with a better bio-coagulation effect. The results showed that this method was especially suitable for the solidification and dust suppression of iron tailings sand and the reinforcement of tailings pond, providing guidance for applying the MICP technology in acidic environments. 
B. sphaericus
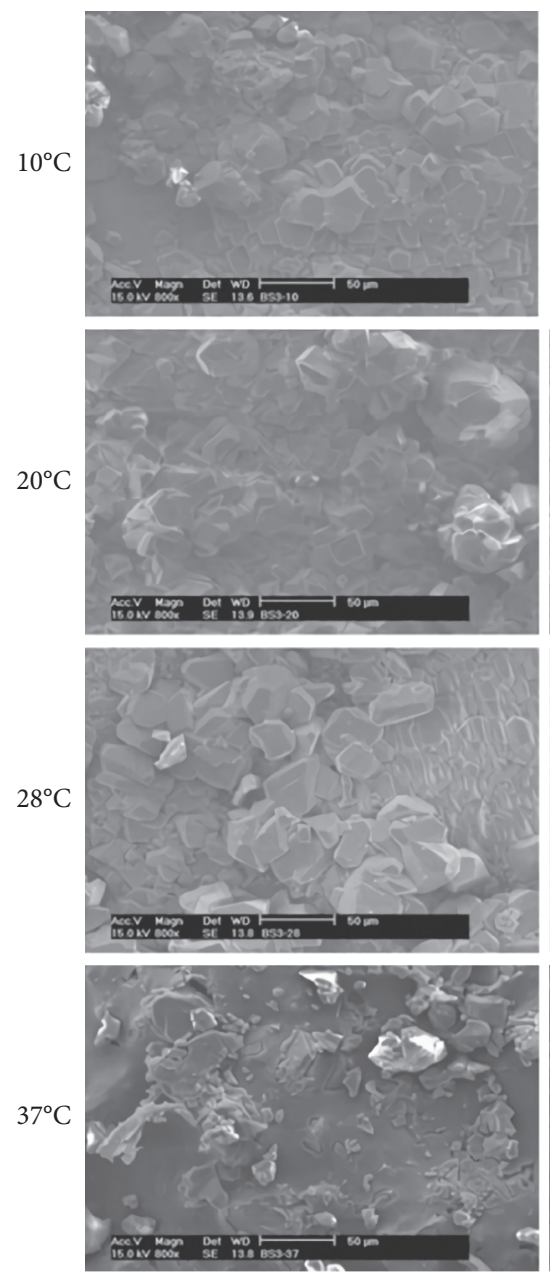

Sp. pasteurii
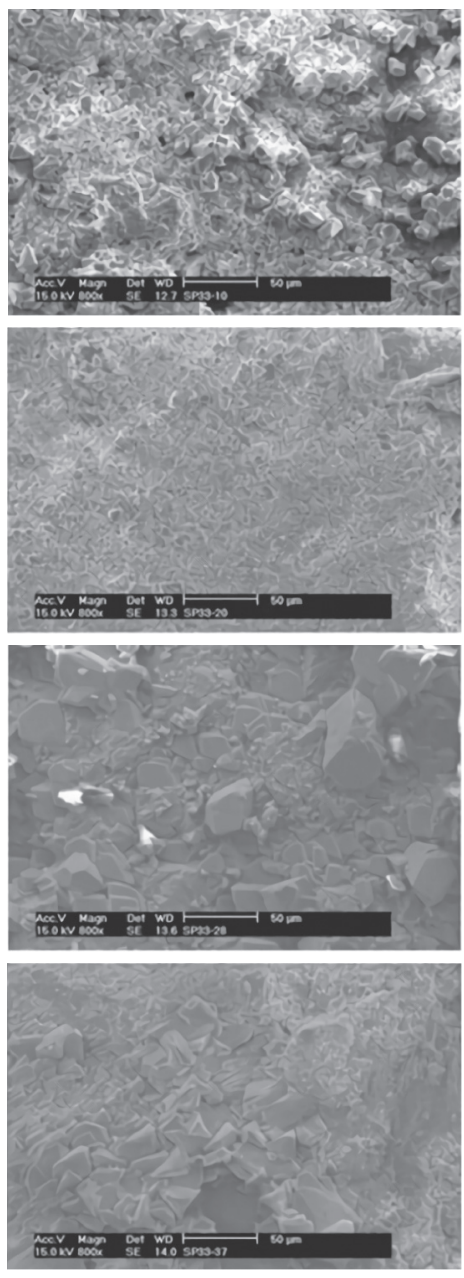

Sp.psychrophila
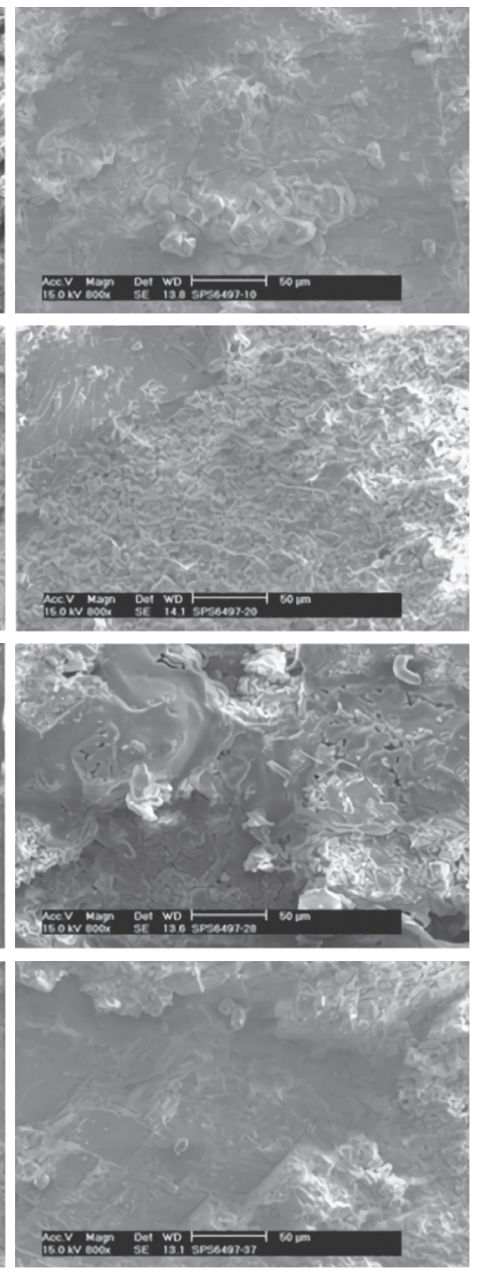

Figure 6: SEM images of different types of crystal precipitation of urealytics at different temperatures [22].

Other studies have shown that the increased $\mathrm{pH}$ leads to increased carbon dioxide demand of growth medium [35]. This phenomenon may be helpful for MICP technology to absorb carbon dioxide and reduce the greenhouse effect.

In the research process, some scholars adjusted the $\mathrm{pH}$ value of the environment from 9.0 to 8.0 , and white precipitates were successfully generated with the introduction of calcium ions. The XRD analysis showed that the main component of precipitates was still calcite. Still, the microstructure and morphology of particles changed significantly, including petal shape and square shape, and the size of particles changed little, as shown in Figure 7 [36].

Studies on the MICP application at different $\mathrm{pH}$ values are conducive to promoting and implementing this environmental-friendly technology.

\section{MICP Application Scenarios}

4.1. Experimental Study. Microbial mineralization and cementation are complex and multidimensional processes that involve biological and nonbiological factors, organic-inorganic factors, and solid-liquid-gas coupling factors. At present, most of the research is still limited to laboratory research. Large-scale and effective practical application research still needs more attention and effort.

Some studies have shown that the overall mechanical properties of concrete were improved by adding the Bacillus subtilis cell wall [37]. The traditional low strain rate indoor pressure test is difficult to study the threat of dynamic disturbance to the cemented backfill. Some scholars [38] studied the high strain rate compression behavior of the cemented backfill under different dynamic loads by using the split Hopkinson pressure bar (SHPB) and determined the failure mode of the specimen through macro and microanalyses. There is little research on the related aspects of microbial cemented backfill. In the process of bacterial mineralization, calcium carbonate was formed by $\mathrm{Ca}^{2+}$ ions and dissolved $\mathrm{CO}_{2}$. The addition of bacterial cell walls increased the carbonation of calcium and the formation of calcium carbonate in concrete. After experimental treatment, the compressive strength of concrete increases by $15 \%$ and the porosity decreases after 28 days of curing. The in vitro calcium carbonate precipitation tests showed that bacterial cell walls, rather than dead cells, accelerated the carbonation of calcium ions in calcium hydroxide solution. Calcium carbonate filled the microvoids in concrete, thus 

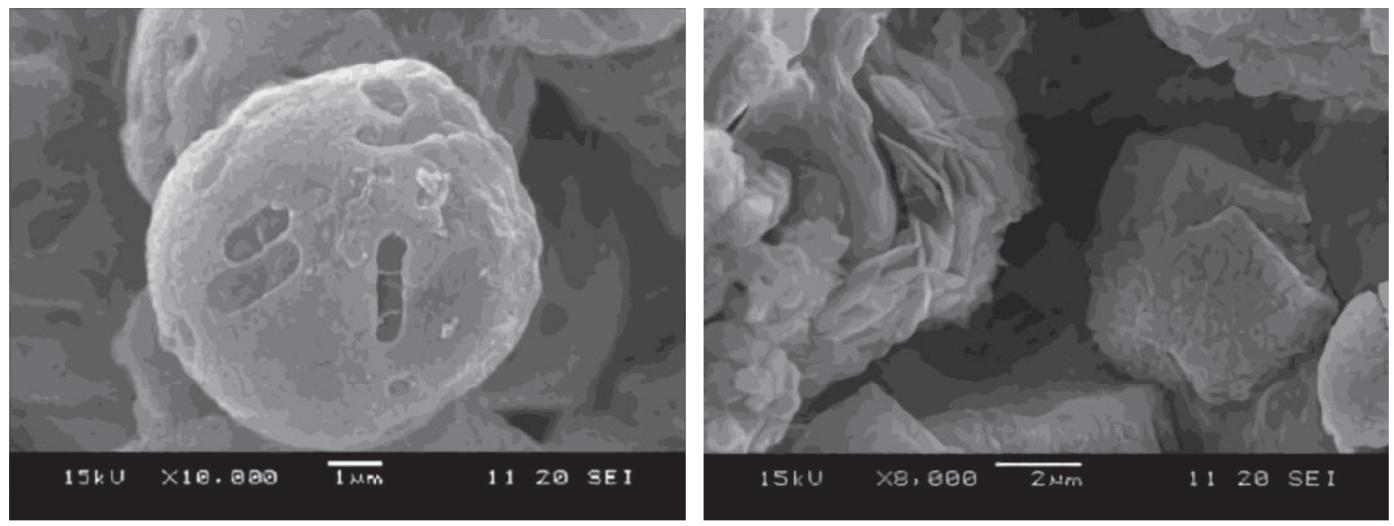

FIgURE 7: SEM images of $\mathrm{CaCO}_{3}$ deposited by microorganism under different $\mathrm{pH}$ conditions [36].

optimizing the MICP process. Thus, the bacterial cell wall was a promising additive in improving concrete's mechanical and carbonation properties.

Erşan et al. [39] revealed that nitrate reduction improved the crack closure performance of microbial mortar. Through the experiment of nitrate-reducing bacteria and two different porous protective carriers, at the end of 56 days, the crack water tightness of the test block was restored to $85 \%$, indicating the self-healing of concrete cracks. As long as there were nutrients in the cracks, the microbial activity continued and might heal larger cracks.

The research [40] proved that different repair methods and calcium source types have significant differences in the repair effect of concrete cracks. The microbial self-healing technology with calcium glutamate as a calcium source had more significant advantages. Thus, Yunus et al. [41] reported that after adding a bioremediation agent to the mortar mixture, the pore volume of mortar increased, and the biobased self-healing mortar had no obvious effect on the development of compressive strength at the age of 28 days. In a series of healing ability tests, after incubation in a water bath for 28 days, the cracks of bacteria-based mortar were healed, which improved the impermeability of bacteriabased mortar.

In the study [42], bacterial spores were first wrapped in hydrogels and then incorporated into specimens to form self-healing to study their healing efficiency. The hydrogelencapsulated spore specimens showed obvious self-healing advantages: the maximum healing crack width was about $0.5 \mathrm{~mm}$ and the permeability decreased by $68 \%$ on average. The maximum healing crack width of other samples of nonbacterial series was $0-0.3 \mathrm{~mm}$; the average permeability is only reduced by $15-55 \%$. The efficiency of self-healing needs to be combined with the actual application environment.

Designing appropriate self-healing efficiency technology and evaluation method in various natural environments is very important. Biological composite cement (bacteria solution, urea/magnesium chloride mixture) was found to bind the loose sand into a biological sandstone, according to [43]. The injection times of bacterial solution had a strong effect on biological sandstone's mechanical properties and porosity. The compressive strength of biological sandstone is positively correlated with the injection time. With an increase in the content of biological composite cement, the pores of the sand column were filled more intensively, while the final defect volume was reduced. The XRCT analysis revealed that the average hardness of solidified natural sandstone was $4.4 \mathrm{~g} / \mathrm{m}^{2} / \mathrm{h}$, while the wind erosion rate was zero.

In addition to these experimental findings, other authors attempted to improve sand properties via the MICP approach. The research [25] confirmed the importance of properly selecting microbial species to enhance mortar's compressive strength. The growth medium had no obvious effect on bacteria, while the type of matrix solution and its molar concentration significantly affected the strength of mortar. The SEM analysis implied that due to the bacterial mineralization precipitation, the fiber material in the pores grew, enhancing the mortar strength.

With the participation of bacteria, the mortar strength was improved by increased porosity and more compact pore size distribution of the cement mortar. The cementation effect of MICP on the sand at different saturations was studied [44], who reported that high soil strength could be obtained at certain calcium carbonate contents. Rong and Qian [10] examined the microbial cementation of loose sand from three aspects: compressive strength, pore structure, and microstructure. Different experimental variables were explored, including soil type (residual tropical soil and sand), soil density $(85,90$, and $95 \%$ of their respective maximum density), and treatment conditions (untreated, treated with cement only, treated with Bacillus megaterium only. and treated with Bacillus megaterium and cement). The results show that MICP effectively improved the shear strength of residual soil and sand, reducing the hydraulic conductivity.

On the other hand, the improvement effect varied with soil density, soil type, and treatment conditions, according to [45], who conducted unidirectional flow tests in a sand column to study the range and distribution of filled pore space under different injection strategies. Compared with the simultaneous injection of Sporosarcina pasteurii and cementation solution (parallel injection), when Pasteurella is injected first, and then cementation solution is injected (phased injection), the precipitation formation and 
distribution were more uniform. In the study [46], MICPtreated sandstone was prepared for the first time. The X-CT technology revealed that the microstructure of natural sandstone became dense with age, the internal defects gradually decreased with time, and the MICP growth rate in sandstone gradually dropped with the decrease of pore size. Different biological agents and cations were used to treat the sand to improve the effect of MICP-based biological cementation. These data can be used as reference values for geotechnical applications, such as biological blocking to reduce sand permeability and biological cementation to improve soil shear strength.

Some studies have confirmed that denitrification-induced carbonate precipitation can also be used for soil improvement and foundation reinforcement [47]. However, because the precipitation rate of carbonate produced by the denitrification method was much lower than that by the urease method, the respective methods need to be further optimized [48].

The process of biological grouting was schematically presented by $\mathrm{Yu}$ et al. [49], as shown in Figure 8.

The eventual aim of biomineralization research is field application. Scale-up experiments have been conducted to demonstrate the feasibility of process application (VAN PAASSEN LA 2009). To evaluate the potential of bio-grout in field application, test volumes of 1 and $100 \mathrm{~m}^{3}$ were used to simulate a three-dimensional environment, which was easily controlled and monitored, under the conditions and injection techniques similar to those envisioned in practice, as shown in Figure 9.

In the $100 \mathrm{~m}^{3}$ experiment, the fluid was $s$ injected in batches through three water injection wells and pumped out by three pumping wells located at a $5 \mathrm{~m}$ distance from the other side. The flow rate was about $1 \mathrm{~m}^{3} \mathrm{H}^{-1}$, and the hydraulic gradient was $0.3 \mathrm{~m} \mathrm{M}^{-1}$. One day after fluid flushing, geophysical measurements (shear wave propagation from the top to the bottom of the cement) revealed a significant (almost tenfold) increase in the average stiffness around the injection point. The artificial cone penetration test proved that after several days of scouring, the cone resistance around the water table exceeded $5 \mathrm{MPa}$.

4.2. Technology Application. MICP technology has been instrumental in restoring and protecting historic buildings and sites [50, 51]. A $100 \mu \mathrm{m}$-thick calcium carbonate film was deposited on the surface of cement paste after seven days' treatment. The capillary suction coefficient of cement paste was reduced by $90 \%$ by brushing bacteria solution on the agar surface. Compared with the spraying method, the brushing method ensured higher urease activity for a long time. When the fine sand, urea, calcium ions, and concentrated bacterial solution were injected into the artificial crack of cement paste, the bacteria produced crystal precipitation under the continuous supplementation of nutrients. The compressive strength of the specimens was restored to $84 \%$ of the initial strength by precipitation crystals, indicating that the bioremediation of surface defects of cement-based materials was quite effective.

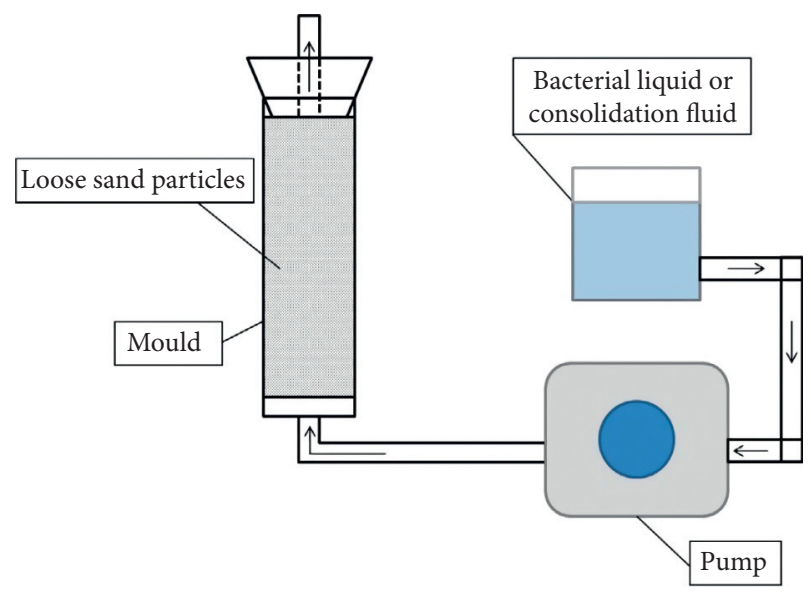

FIGURE 8: Schematic diagram of the bio-grouting process [49].

The research [52] focused on the durability of cementitious materials formed during the MICP action. The biological deposition treatment improved mortar samples' carbonation, chloride ion penetration, and freeze-thaw resistance values. The coating system could reduce the permeability of cementitious materials and improve the durability of the treated interface. Some scholars have proposed a microbial precipitation protection method for calcareous weathered stone carvings. This method did not introduce foreign substances into the internal porous network of the protection object, which was suitable for protecting marble statues and works of art [53]. Some experiments used noninoculated culture media to activate natural microbial colonies in quarry limestone and consolidate them in porous media without blocking pores. This may be more suitable and safe to protect ornamental stones. Jimenez-Lopez et al. [54] reported that the bacterial enzyme digestion method could greatly increase cement test block's surface impermeability and acid and alkali resistance. Adding the best concentration of calcium ions before adding urea and bacteria could play to the sedimentary layer's best protection effect, with a good application prospect in the surface protection of building materials [55].

The unconfined compressive strength of the two kinds of soil after being treated with MICP technology was significantly improved (by 1.5-2.9 times) and the soil strength increased with the treatment time. Compared with other soil improvement technologies in practice, the cost of the microbial agent was relatively low. As an additional advantage, MICP was a green, stable, sustainable, and eco-friendly emerging technology with broad prospects [56]. Some research methods have reduced the production cost by $95 \%$ and produced a high level of urease activity (hydrolysis of $21 \mathrm{mmol}$ urea per minute) at a low cost (0.20 USD per liter) in the new medium, which was encouraging and guiding for MICP to go out of laboratory research and enter field application [32]). When the mixture of urea and seawater was used to treat the sandy soil through porous sand instead of a high concentration of calcium and urea solution, the UCS was increased twice under the condition of producing the same number of crystals. The test sample strength increased, while the permeability was maintained by a $30 \%$ level, 

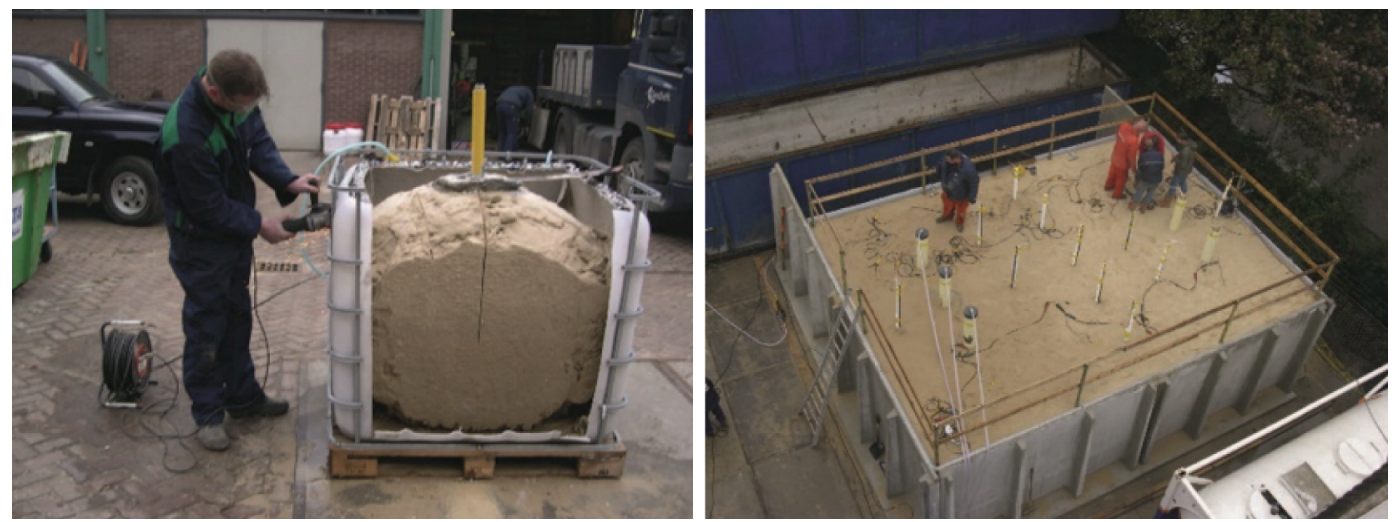

FIgURE 9: A wide range of experimental devices for biological cementation $\left(1 \mathrm{~m}^{3}\right.$ and $\left.100 \mathrm{~m}^{3}\right)$ [32].

indicating good drainage capacity. This new exploration of MICP technology provided great potentials for applying biocementation technology in the marine environment, such as slowing down the liquefaction of seabed sediments, preventing beach sand erosion and cliff erosion, etc. [57, 58].

In vivo soil engineering is a new interdisciplinary method, which regards soil as a living, active, and biochemical system capable of providing sustainable solutions. The proposed framework and method of this technology, as well as the relationship and interaction between these different components, are shown in Figure 10 [59].

Experiments and numerical simulations, including timely process monitoring, have made significant progress in understanding and controlling MICP at all length scales. Some researchers carried out 720 UCS tests under different levels of factors. They collected the strength evaluation database and verified the feasibility of the prediction model [60]. If a similar model can be established in the performance research of microbial cemented backfill, the experimental process will be greatly optimized, and the research efficiency will be improved. It is very promising that MICP can be applied to improve soil mechanical and hydraulic properties, immobilize heavy metals, and sequester atmospheric carbon in the future [59]. As early as 1987, some scholars put forward the possibility of bacteria as the nucleation sites of authigenic minerals to control metal pollution. Forming a gelatinous matrix around the granular matter in structure and chemical composition was found conducive to bacteria cementing and fixing metal ions [61]. A possible long-term remediation strategy for groundwater pollution in studying pollutant calcite coprecipitation with atcc 11859 bacteria was outlined by [62]. The enrichment experiments of indigenous microorganisms capable of internal soil engineering hydrolyzing urea in the presence of calcium chloride were carried out under laboratory and field conditions. The results showed that when the soil was treated with nutrients, $\mathrm{CaCl}_{2}$, and urea, a large amount of calcite would be precipitated in the soil depth by indigenous microorganisms, which greatly enhanced their ability to resist earthquake liquefaction. The indigenous microbial enrichment process could be used in the field on a large scale because it required no cultivation of foreign bacteria, and the technology cost was lower. Using local bacteria to induce calcite precipitation to improve soil was less invasive to owners and less toxic to the environment [63]. The local microbial colonies were activated to cement the porous media in the quarry limestone without introducing new inoculated bacteria while maintaining a certain permeability [54]. Burbank et al. [63] conducted cone penetration tests and cyclic triaxial shear tests using natural primary bacteria to induce calcite precipitation. The results showed that primary bacteria could significantly change soil engineering properties, improve sand liquefaction resistance, and have economic advantages over exogenous bacteria.

The bacteria were permanently adsorbed on the sand by injecting the bacteria solution into the sand body first and then the fixed solution (i.e., the solution with high salt content). This method could prevent the blockage in the process of injection, the reinforcement effect was more uniform, and the effect and efficiency of foundation reinforcement were improved [64]. Reservoir permeability was the key factor of water drive oil recovery. Bacterial precipitate crystal was a temporary plugging agent, which could permanently block and significantly reduce the permeability of porous media. The successful application of MICP technology in the water-driven oil recovery industry needed further screening and domestication [65]. As early as 1996, some scholars proposed using microbial precipitation as a plugging agent and cementing agent for porous media. This process could be used to exploit underground reservoirs and cement loose sand and control the flow of pollutants in aquifers [66]. By introducing the development opportunities of MICP in new interdisciplinary fields such as microbiology, geochemistry, and civil engineering, the publication [67] outlined the advantages of biological mediated soil improvement, evaluated the change of pore space volume and distribution characteristics in soil by calcite precipitation through microtechnology, and analyzed the advantages and restrictions of the MICP technology in terms of microbial and soil size compatibility. The mature application of MICP technology can largely cement and improve the structure of the loose sand layer. With the maturity of this "green" technology, new possibilities could be created in soil improvement, including the treatment of liquefiable sand layer, underground pretreatment before tunnel excavation, reduction of building settlement, and stability of the dam, 


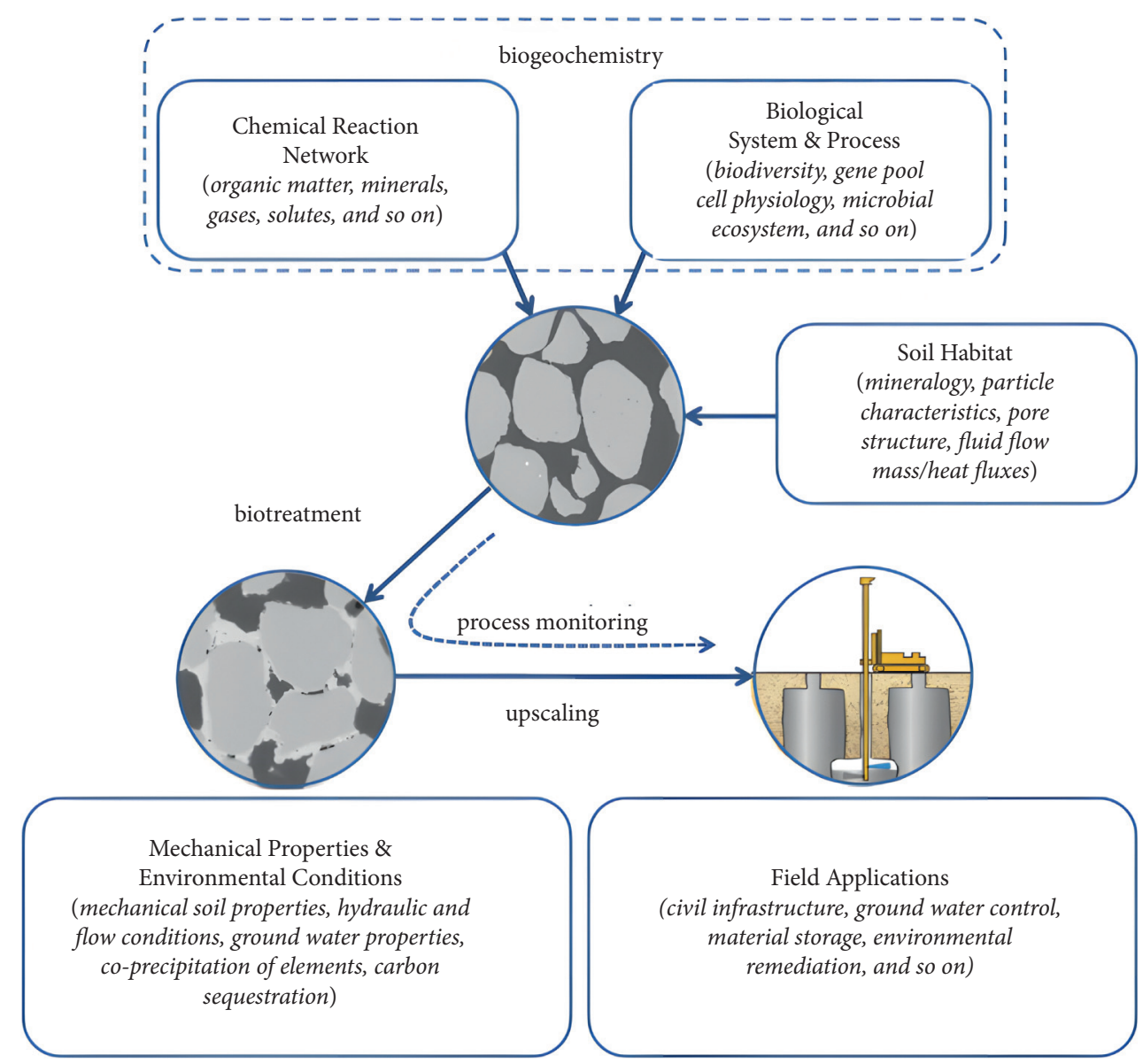

FIGURE 10: Schematic diagram of the method framework of "internal soil engineering." A more in-depth representation can be found elsewhere [59].

embankment, and slope [7]. Some scholars have studied that after the gas pipeline is corroded underground, it is more obviously affected by the vibration of blasting engineering [68]. According to the research results of the above authors, the quality of underground soil will be greatly improved after microbial modification. Whether this operation can have a good effect in resisting blasting vibration is also worth studying. The bacteria will be permanently adsorbed on the sand by injecting the bacteria solution into the sand body first and then the fixed solution (i.e., the solution with high salt content). This method can prevent blockage in the process of injection, ensure a more uniform reinforcement effect, and enhance the efficiency of foundation reinforcement [64].

Research efforts have also been focused on establishing a mathematical model to predict the simple biogeochemical reaction migration consistent with the experimental data. Thus, such a model elaborated for half-meter one-dimensional sand column quite accurately reflects the changes in the micropollutant treatment scheme and provide a finecontrol idea for microbial soil improvement $[69,70]$. The MICP technology has the advantage of green ecology in the aspect of calcium carbonate deposition. The scientific community speculates whether the MICP repair technology can be used based on the research on the mechanical properties of rock mass, in the aspect of rock mass damage and strength recovery after damage, and then in the aspect of mine vibration reduction after rock mass damage repair.

Figure 11 shows the active process of MICP in selfrepairing concrete, the process of dust suppression, the application scenario, and the feasibility study prospect of desert control.

The metabolic activities of bacterial cells can effectively improve the geo-mechanical properties of sand. Growing cells improve the properties of sand, while dead cells and resting cells usually lead to a small increase in friction angle and bearing strength. Using MICP technology in low saturation formation can obtain higher soil strength under similar calcium carbonate content. This important finding shows that this stabilization process can achieve the best performance at a lower cost. This process reduces the demand for water and chemicals, making it more economically viable. Therefore, the technology will likely become more environmentally friendly than previously thought sustainability $[44,71]$.

In the study of [72], Bacillus megaterium was used to trigger calcite precipitation. The results showed that the engineering properties of typical tropical residual soil treated by MICP were similar to those treated by fine sand; the shear strength and hydraulic conductivity increased by 69 and 


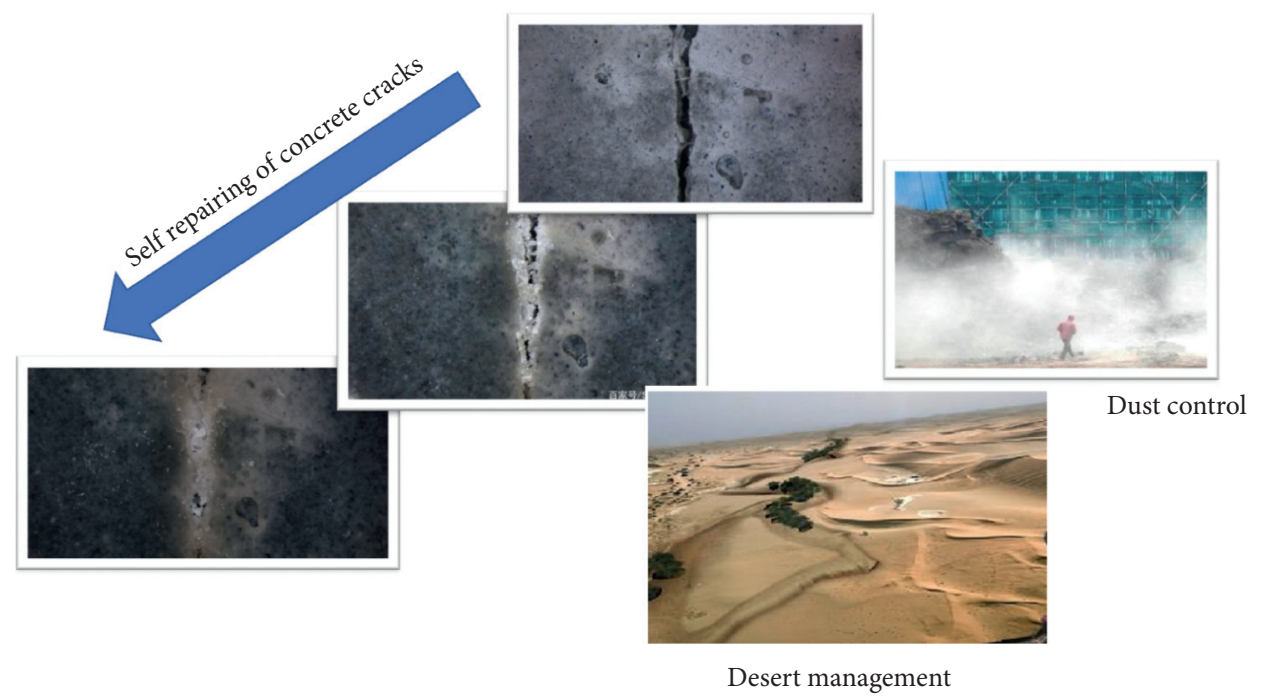

FIgURE 11: Application scenarios of MICP technology.

$90 \%$, respectively. The performance of sand changed from "soil-like" to "rock-like" with the improvement of treatment level. The dynamic test results [73] show confirmed that the antiliquefaction ability of MICP-treated sand significantly exceeded that of the untreated loose sand.

\section{Discussion and Technology Prospects}

This review covered the current development of MICP technology and the prospects of different application approaches. As a new interdisciplinary technology with good environmental adaptability, MICP technology has developed rapidly in the past two decades. Despite some field applications, the wide implementation of MICP was limited by several problematic issues. To mitigate them, the following tasks need to be properly formulated and resolved via innovative technologies:

(1) Reducing the cost of technology is still a key factor for the large-scale application of biomineralization engineering. At present, the cost of MICP technology is relatively high, which hinders the large-scale application.

(2) The treatment of by-products (such as ammonia) in the process of biomineralization has not been reasonably solved. The promotion of this technology should avoid generating harmful substances to the environment (e.g., ammonia). Meanwhile, some studies show that the biomineralization process may absorb carbon dioxide, reducing the greenhouse effect [35].

(3) It is very difficult for geotechnical engineers to obtain strains that meet the actual needs of professional genetic transformation technology. It needs the strong support of biological process professionals. Interdisciplinary cooperation should be closer in the future.

(4) There are huge differences in available application scenarios, which lead to the lack of a unified and effective implementation strategy. The domestication of local bacteria is considered a breakthrough solution [63]. This approach can avoid polluting the local environment with foreign bacteria and reduce construction costs.

\section{Conflicts of Interest}

The authors declare that they have no conflicts of interest.

\section{Acknowledgments}

The authors acknowledge the financial support from the National Natural Science Foundation Project of China (Xiuzhi Shi, Grant no. 51874350), National Key R\&D Program of China (Xiuzhi Shi, 2017YFC0602902), and Hunan Provincial Natural Science Foundation Project (2021JJ40733) for carrying out this research work.

\section{References}

[1] J. Chu, V. Ivanov, V. Stabnikov, and B. Li, "Microbial method for construction of an aquaculture pond in sand," Géotechnique, vol. 63, no. 10, pp. 871-875, 2013.

[2] C.-S. Tang, L.-Y. Yin, N.-J. Jiang et al., "Factors affecting the performance of microbial-induced carbonate precipitation (MICP) treated soil: a review," Environmental Earth Sciences, vol. 79, no. 5, p. 94, 2020.

[3] J. Chu, V. Ivanov, J. He, M. Naeimi, B. Li, and V. Stabnikov, Development of Microbial Geotechnology in Singapore. GeoFrontiers 2011, pp. 4070-4078, American Society of Civil Engineers, Dallas, Texas, United States, 2011.

[4] J. Chu, V. Stabnikov, and V. Ivanov, "Microbially induced calcium carbonate precipitation on surface or in the bulk of soil," Geomicrobiology Journal, vol. 29, no. 6, pp. 544-549, 2012.

[5] V. Ivanov and J. Chu, "Applications of microorganisms to geotechnical engineering for bioclogging and biocementation of soil in situ," Reviews in Environmental Science and Biotechnology, vol. 7, no. 2, pp. 139-153, 2008. 
[6] J. K. Mitchell and J. Carlos Santamarina, "Biological considerations in geotechnical engineering," Journal of Geotechnical and Geoenvironmental Engineering, vol. 131, no. 10, pp. 1222-1233, 2005.

[7] J. T. DeJong, M. B. Fritzges, and K. Nüsslein, "Microbially induced cementation to control sand response to undrained shear," Journal of Geotechnical and Geoenvironmental Engineering, vol. 132, no. 11, pp. 1381-1392, 2006.

[8] W. De Muynck, N. De Belie, and W. Verstraete, "Microbial carbonate precipitation in construction materials: a review," Ecological Engineering, vol. 36, pp. 118-136, 2010.

[9] Y. Fujita, F. G. Ferris, R. D. Lawson, F. S. Colwell, and R. W. Smith, "Calcium carbonate precipitation by ureolytic subsurface bacteria," Geomicrobiology Journal, vol. 17, no. 4, pp. 305-318, 2000.

[10] H. Rong and C.-X. Qian, "Development of microbe cementitious material in China," Journal of Shanghai Jiaotong University, vol. 17, no. 3, pp. 350-355, 2012.

[11] J. T. Dejong, K. Soga, E. Kavazanjian et al., "Biogeo chemical processes and geotechnical applications: progress, opportunities and challenges," Géotechnique, vol. 63, no. 4, pp. 287-301, 2013.

[12] C. M. Gorospe, S.-H. Han, S.-G. Kim et al., "Effects of different calcium salts on calcium carbonate crystal formation by Sporosarcina pasteurii KCTC 3558," Biotechnology and Bioprocess Engineering, vol. 18, no. 5, pp. 903-908, 2013.

[13] V. Achal and X. Pan, "Influence of calcium sources on microbially induced calcium carbonate precipitation by $\mathrm{Ba}-$ cillus sp. CR2," Applied Biochemistry and Biotechnology, vol. 173, no. 1, pp. 307-317, 2014.

[14] B. M. Mortensen, M. J. Haber, J. T. DeJong, L. F. Caslake, and D. C. Nelson, "Effects of environmental factors on microbial induced calcium carbonate precipitation: environmental factors on MICP," Journal of Applied Microbiology, vol. 111, no. 2, pp. 338-349, 2011.

[15] D. Kim, K. Park, and D. Kim, "Effects of ground conditions on microbial cementation in soils," Materials, vol. 7 , no. 1 , pp. 143-156, 2013.

[16] M. Kitamura, H. Konno, A. Yasui, and H. Masuoka, "Controlling factors and mechanism of reactive crystallization of calcium carbonate polymorphs from calcium hydroxide suspensions," Journal of Crystal Growth, vol. 236, no. 1-3, pp. 323-332, 2002.

[17] V. Ivanov, J. Chu, and V. Stabnikov, "Basics of construction microbial biotechnology," in Biotechnologies and Biomimetics for Civil Engineering, F. Pacheco Torgal, J. A. Labrincha, M. V. Diamanti, C.-P. Yu, and H. K. Lee, Eds., Springer International Publishing, Cham, pp. 21-56, 2015.

[18] N. K. Dhami, "Biomineralization of calcium carbonate polymorphs by the bacterial strains isolated from calcareous sites," Journal of Microbiology and Biotechnology, vol. 23, no. 5, pp. 707-714, 2013.

[19] G. D. O. Okwadha and L. Jin, "Optimum conditions for microbial carbonate precipitation," Chemosphere, vol. 81, no. 9, pp. 1143-1148, 2010.

[20] K. Eryürük, S. Yang, D. Suzuki et al., "Reducing hydraulic conductivity of porous media using $\mathrm{CaCO} 3$ precipitation induced by Sporosarcina pasteurii," Journal of Bioscience and Bioengineering, vol. 119, no. 3, pp. 331-336, 2015.

[21] V. Achal, A. Mukherjee, P. C. Basu, and M. S. Reddy, "Strain improvement of Sporosarcina pasteurii for enhanced urease and calcite production," Journal of Industrial Microbiology \& Biotechnology, vol. 36, no. 7, pp. 981-988, 2009.
[22] De Muynck, Willem, V. Kim, N. De Belie, and W. Verstraete, "Influence of temperature on the effectiveness of a biogenic carbonate surface treatment for limestone conservation," Applied Microbiology and Biotechnology, vol. 97, no. 3, pp. 1335-1347, 2013.

[23] K. L. Bachmeier, A. E. Williams, J. R. Warmington, and S. S. Bang, "Urease activity in microbiologically-induced calcite precipitation," Journal of Biotechnology, vol. 93, no. 2, pp. 171-181, 2002.

[24] J. Tourney and B. T. Ngwenya, "Bacterial extracellular polymeric substances (EPS) mediate $\mathrm{CaCO} 3$ morphology and polymorphism," Chemical Geology, vol. 262, no. 3-4, pp. 138-146, 2009.

[25] Y. Al-Salloum, H. Abbas, Q. I. Sheikh, S. Hadi, and S. Alsayed, "Effect of some biotic factors on microbially-induced calcite precipitation in cement mortar," Saudi Journal of Biological Sciences, vol. 24, no. 2, pp. 286-294, 2017.

[26] Q. I. A. N. ChunXiang, R. O. N. G. Hui, X. N. Yu, and $\mathrm{X}$. Wang, "Experiments on and predictions about properties of sand bonded by microbe cement," Science China Technological Sciences, vol. 59, p. 8, 2016.

[27] C. Liang, Q. Chunxiang, and W. Ruixing, "Study on the mechanism of calcium carbonate formation induced by carbonate-mineralization microbe," Acta Chim Sinica, vol. 65, no. 19, pp. 2133-2138, 2007.

[28] A. Al Qabany, K. Soga, and C. Santamarina, "Factors affecting efficiency of microbially induced calcite precipitation," Journal of Geotechnical and Geoenvironmental Engineering, vol. 138, no. 8, pp. 992-1001, 2012.

[29] A. A. Qabany and K. Soga, "Effect of chemical treatment used in MICP on engineering properties of cemented soils," Géotechnique, vol. 63, no. 4, pp. 331-339, 2013.

[30] S. Al-Thawadi and R. Cord-Ruwisch, "Calcium carbonate crystals formation by ureolytic bacteria isolated from Australian soil and sludge," BioCementation, vol. 2, 2012.

[31] Z. Hu and Y. Deng, "Supersaturation control in aragonite synthesis using sparingly soluble calcium sulfate as reactants," Journal of Colloid and Interface Science, vol. 266, no. 2, pp. 359-365, 2003.

[32] L. A. VAN Paassen, "Bio-grout," Ground Improvement by Microbial Induced Carbonate Precipitation', Delft University of Technology, Netherlands, 2009.

[33] V. S. Whiffin, Microbial CaCO3 Precipitation for the Production of Bio-Cement, Pdf. PHD, 2004.

[34] Y. Lai, Y. Jin, S. Liu, J. Liu, R. Wang, and B. Dong, "Experimental study to improve the mechanical properties of iron tailings sand by using MICP at low $\mathrm{pH}$," Construction and Building Materials, vol. 273, Article ID 121729, 2021.

[35] T. O. Okyay and D. F. Rodrigues, "Biotic and abiotic effects on $\mathrm{CO} 2$ sequestration during microbially-induced calcium carbonate precipitation," FEMS Microbiology Ecology, vol. 91, no. 3, 2015.

[36] R. Wang, C. Qian, and J. Wang, "Study on microbial deposition of calcium carbonate," Journal of Southeast University (NATURAL SCIENCE EDITION, no. S1, pp. 191-195, 2005.

[37] R. Pei, J. Liu, S. Wang, and M. Yang, "Use of bacterial cell walls to improve the mechanical performance of concrete," Cement and Concrete Composites, vol. 39, pp. 122-130, 2013.

[38] X. Chen, X. Shi, J. Zhou, E. Li, P. Qiu, and Y. Gou, "High strain rate compressive strength behavior of cemented paste backfill using split Hopkinson pressure bar," International Journal of Mining Science and Technology, vol. 31, pp. 387399, 2021. 
[39] Y. Ç. Erşan, E. Hernandez-Sanabria, N. Boon, and N. de Belie, "Enhanced crack closure performance of microbial mortar through nitrate reduction," Cement and Concrete Composites, vol. 70, pp. 159-170, 2016.

[40] J. Xu and Y. Wu, "Multiscale mechanical quantification of self-healing concrete incorporating non-ureolytic bacteriabased healing agent," Cement and Concrete Research, vol. 64, pp. 1-10, 2014.

[41] B. Yunus, E. Schlangen, and H. M. Jonkers, "Bio-based selfhealing mortar," International Journal of Integrated Engineering, vol. 10, 2019.

[42] J. Y. Wang, D. Snoeck, S. Van Vlierberghe, W. Verstraete, and N. De Belie, "Application of hydrogel encapsulated carbonate precipitating bacteria for approaching a realistic self-healing in concrete," Construction and Building Materials, vol. 68, pp. 110-119, 2014.

[43] B. De, E. G. Nele, A. Al-Tabbaa et al., "A review of self-healing concrete for damage management of structures," Advanced Materials Interfaces, vol. 5, no. 17, Article ID 1800074, 2018.

[44] L. Cheng, R. Cord-Ruwisch, and M. A. Shahin, "Cementation of sand soil by microbially induced calcite precipitation at various degrees of saturation," Canadian Geotechnical Journal, vol. 50, no. 1, pp. 81-90, 2013.

[45] N. W. Soon, L. M. Lee, T. C. Khun, and H. S. Ling, "Improvements in engineering properties of soils through microbial-induced calcite precipitation," KSCE Journal of Civil Engineering, vol. 17, no. 4, pp. 718-728, 2013.

[46] D. J. Tobler, E. Maclachlan, and V. R. Phoenix, "Microbially mediated plugging of porous media and the impact of differing injection strategies," Ecological Engineering, vol. 42, pp. 270-278, 2012.

[47] J. Chu, I. Volodymyr, N. Maryam, S. Viktor, and L. L. Han, "Optimization of calcium-based bio-clogging and bio-cementation of sand," Acta Geotechnica, vol. 9, no. 2, pp. 277-285, 2014.

[48] V. Paassen, A. Leon, C. M. Daza et al., "Potential soil reinforcement by biological denitrification," Ecological Engineering, vol. 36, no. 2, pp. 168-175, 2010.

[49] X. Yu, C. Qian, and L. Sun, "The influence of the number of injections of bio-composite cement on the properties of biosandstone cemented by bio-composite cement," Construction and Building Materials, vol. 164, pp. 682-687, 2018.

[50] M. Willem, K. Cox, N. De Belie, and W. Verstraete, "Bacterial carbonate precipitation as an alternative surface treatment for concrete," Construction and Building Materials, vol. 22, no. 5, pp. 875-885, 2008.

[51] C. Qian, R. Wang, L. Cheng, and J. Wang, "Theory of microbial carbonate precipitation and its application in restoration of cement-based materials defects," Chinese Journal of Chemistry, vol. 28, pp. 847-857, 2010.

[52] W. Muyncka, D. Debrouwer, N. Belie, and W. Verstraete, "Bacterial carbonate precipitation improves the durability of cementitious materials," Cement and Concrete Research, vol. 38, no. 7, pp. 1005-1014, 2008.

[53] P. Tiano, E. Cantisani, I. Sutherland, and J. M. Paget, "Biomediated reinforcement of weathered calcareous stones," Journal of Cultural Heritage, vol. 7, no. 1, pp. 49-55, 2006.

[54] C. Jimenez-Lopez, F. Jroundi, C. Pascolini et al., "Consolidation of quarry calcarenite by calcium carbonate precipitation induced by bacteria activated among the microbiota inhabiting the stone," International Biodeterioration \& Biodegradation, vol. 62, no. 4, pp. 352-363, 2008.

[55] Q. Chunxiang, J. Wang, R. Wang, and C. Liang, "Corrosion protection of cement-based building materials by surface deposition of $\mathrm{CaCO} 3$ by Bacillus pasteurii," Materials Science and Engineering: C, vol. 29, no. 4, pp. 1273-1280, 2009.

[56] A. Sharma and R. Ramkrishnan, "Study on effect of microbial induced calcite precipitates on strength of fine grained soils," Perspectives in Science, vol. 8, pp. 198-202, 2016.

[57] L. Cheng, M. A. Shahin, and R. Cord-Ruwisch, "Bio-cementation of sandy soil using microbially induced carbonate precipitation for marine environments," Géotechnique, vol. 64, no. 12, pp. 1010-1013, 2014.

[58] L. Cheng, M. A. Shahin, R. Cord-Ruwisch, M. Addis, T. Hartanto, and C. Elms, "Soil stabilization by microbialinduced calcite precipitation (MICP): investigation into some physical and environmental aspects," in Proceedings of the 7th International Congress on Environmental Geotechnics, Melbourne, Australia, Nov 2014.

[59] J. T. DeJong, S. Kenichi, S. A. Banwart et al., "Soil engineering in vivo: harnessing natural biogeochemical systems for sustainable, multi-functional engineering solutions," Journal of The Royal Society Interface, vol. 8, no. 54, pp. 1-15, 2011.

[60] Z. Yu, X.-Z. Shi, X. Chen et al., "Artificial intelligence model for studying unconfined compressive performance of fiber-reinforced cemented paste backfill," Transactions of Nonferrous Metals Society of China, vol. 31, no. 4, pp. 1087-1102, 2021.

[61] F. G. Ferris, W. S. Fyfe, and T. J. Beveridge, "Bacteria as nucleation sites for authigenic minerals in a metal-contaminated lake sediment," Chemical Geology, vol. 63, no. 3-4, pp. 225-232, 1987.

[62] A. C. Mitchell and F. Grant Ferris, "The coprecipitation of Sr into calcite precipitates induced by bacterial ureolysis in artificial groundwater: temperature and kinetic dependence," Geochimica et Cosmochimica Acta, vol. 69, no. 17, pp. 4199-4210, 2005.

[63] M. B. Burbank, T. J. Weaver, T. L. Green, B. C. Williams, and R. L. Crawford, "Precipitation of calcite by indigenous microorganisms to strengthen liquefiable soils," Geomicrobiology Journal, vol. 13, pp. 301-312, 2013.

[64] M. P. Harkes, L. A. van Paassen, J. L. Booster, V. S. Whiffin, and M. C. M. van Loosdrecht, "Fixation and distribution of bacterial activity in sand to induce carbonate precipitation for ground reinforcement," Ecological Engineering, vol. 36, no. 2, pp. 112-117, 2010.

[65] M. Nemati, E. A. Greene, and G. Voordouw, "Permeability profile modification using bacterially formed calcium carbonate: comparison with enzymic option," Process Biochemistry, vol. 40, no. 2, pp. 925-933, 2005.

[66] F. G. Ferris, L. G. Stehmeier, A. Kantzas, and F. M. Mourits, Bacteriogenic Mineral Plugging, 1996.

[67] J. T. DeJong, B. M. Mortensen, B. C. Martinez, and D. C. Nelson, "Bio-mediated soil improvement," Ecological Engineering, vol. 36, no. 2, pp. 197-210, 2010.

[68] Z. Bin, J. Nan, Z. Chuanbo, X. Luo, Y. Yao, and T. Wu, "Dynamic failure behavior of buried cast iron gas pipeline with local external corrosion subjected to blasting vibration," Journal of Natural Gas Science and Engineering, vol. 88, Article ID 103803, 2021.

[69] T. H. Barkouki, B. C. Martinez, B. M. Mortensen et al., "Forward and inverse bio-geochemical modeling of microbially induced calcite precipitation in half-meter column experiments," Transport in Porous Media, vol. 90, no. 1, pp. 23-39, 2011.

[70] B. C. Martinez, J. T. DeJong, and T. R. Ginn, "Bio-geochemical reactive transport modeling of microbial induced calcite precipitation to predict the treatment of sand in onedimensional flow," Computers and Geotechnics, vol. 58, pp. 1-13, 2014. 
[71] C.-W. Chou, E. A. Seagren, A. H. Aydilek, and M. Lai, "Biocalcification of sand through ureolysis," Journal of Geotechnical and Geoenvironmental Engineering, vol. 137, no. 12, pp. 1179-1189, 2011.

[72] N. W. Soon, L. M. Lee, T. C. Khun, and H. S. Ling, "Factors affecting improvement in engineering properties of residual soil through microbial-induced calcite precipitation," Journal of Geotechnical and Geoenvironmental Engineering, vol. 140, no. 5, Article ID 04014006, 2014.

[73] B. M. Montoya, J. T. Dejong, and R. W. Boulanger, "Dynamic response of liquefiable sand improved by microbial-induced calcite precipitation," Géotechnique, vol. 63, no. 4, pp. 302-312, 2013. 